\title{
Strain variation, based on the hemagglutinin gene, in Norwegian ISA virus isolates collected from 1987 to 2001: indications of recombination
}

\author{
M. Devold ${ }^{1}$, K. Falk ${ }^{2}$, O. B. Dale ${ }^{2}$, B. Krossøy ${ }^{3}$, E. Biering ${ }^{3}$, V. Aspehaug ${ }^{2}$, F. Nilsen ${ }^{1}$, \\ A. Nylund ${ }^{1, *}$ \\ ${ }^{1}$ Department of Fisheries and Marine Biology, University of Bergen, 5020 Bergen, Norway \\ ${ }^{2}$ National Veterinary Institute, Section of Aquatic Animal Health, 0033 Oslo, Norway \\ ${ }^{3}$ Intervet Norbio, 5020 Bergen, Norway
}

\begin{abstract}
Infectious salmon anemia (ISA) is caused by a virus that probably belongs to the Orthomyxoviridae and was first recorded in Norway in 1984. The disease has since spread along the Norwegian coast and has later been found in Canada, Scotland, the Faroe Islands, Chile, and the USA. This study presents sequence variation of the hemagglutinin gene from 37 ISA virus isolates, viz. one isolate from Scotland, one from Canada and 35 from Norway. The hemagglutinin gene contains a highly polymorphic region (HPR), which together with the rest of the gene sequence provides a good tool for studies of epizootics. The gene shows temporal and geographical sequence variation, where certain areas are dominated by distinct groups of isolates. Evidence of transmission of ISA virus isolates within and between regions is given. It is suggested that the hemagglutinin gene from different isolates may recombine. Possible recombination sites are found within the HPR and in the 5 '-end flanking region close to the HPR.
\end{abstract}

KEY WORDS: ISAV · Hemagglutinin $\cdot$ Strain variation $\cdot$ Recombination

Resale or republication not permitted without written consent of the publisher

\section{INTRODUCTION}

Infectious salmon anemia (ISA) was first officially registered in Bremnes, Norway, in 1984. However, ISA virus (ISAV)-like particles have been found in tissues from salmon with hemorrhagic syndrome collected in 1977 and 1978, which indicate that the disease could have been present in Norwegian aquaculture as early as in the late 1970s (pers. obs.). At this time hemorrhagic syndrome probably included several different diseases. Later, in the 1980s, ISA was sometimes confused with 'Hitra' disease (cold water vibriosis) and cardiac myopathy syndrome (CMS). It was not until 1995, when safe and sensitive diagnostic tools became available, that ISA could be safely distinguished from other diseases in salmon culture. At present, ISA has

*Corresponding author. E-mail: are.nylund@ifm.uib.no been diagnosed in most major salmon producing countries: Norway, Canada (Mullins et al. 1998, Jones \& MacKinnon 1999, Lovely et al. 1999), Great Britain (Rodger et al. 1998, Rowley et al. 1999), the Faroe Islands (pers. obs.), Chile (Kibenge et al. 2001), and the USA (Bouchard et al. 2001). The causative agent, the ISA virus, has a negative-stranded, segmented, RNA genome and it has been suggested that it belongs to the family Orthomyxoviridae (Falk et al. 1997, Koren \& Nylund 1997, Mjaaland et al. 1997, Krossøy et al. 1999, Eliassen et al. 2000, Sandvik et al. 2000).

ISAV infects several different salmonid species (Salmo salar, S. trutta, Oncorhynchus spp., and Salvelinus alpinus) in the North Atlantic (Nylund et al. 1997, Devold et al. 2000, Kibenge et al. 2001, Snow et al. 2001). If this virus follows the same pattern of distribution as the hosts, one should expect to find distinct isolates reflecting the distribution of host species, since interspecies transmission, combined with geographic 
isolation of host species, is expected to contribute to the evolutionary divergence of viruses because of the separation of host-specific virus gene pools. This could possibly explain the distinct differences between ISAV isolates from New Brunswick (Canada), where Oncorhynchus species are the dominating salmonids, and Europe, where Salmo is the dominating salmonid genus (Blake et al. 1999, Inglis et al. 2000, Kibenge et al. 2001, Krossøy et al. 2001a). However, one isolate from Nova Scotia (Canada) shows greater similarity to ISAV from Norway and Scotland than to ISAV from New Brunswick, but this isolate could have been recently transferred from Europe to Canada through the transfer of aquaculture material (cf. Ritchie et al. 2001). These studies are based on sequence comparisons of segments 2 (Krossøy et al. 1999) and 8 (Mjaaland et al. 1997) of ISAV. It has, however, not been possible to separate the different European isolates due to little variation in the gene segments studied (Krossøy et al. 2001a). If more variation can be found in one of the other gene segments of the ISAV, the distribution pattern of isolates in Norway should reflect the biology of the hosts (Atlantic salmon and trout) and the fact that in the last 2 decades salmon farming and transportation of cultured salmonids may have had a strong influence on the distribution pattern of ISAV isolates.

Mutations, including substitutions, deletions, and insertions, are one of the most important mechanisms for producing variation in influenza viruses (Webster et al. 1992). Reassortment is an additional mechanism for producing variation very rapidly in viruses with segmented genomes. Another mechanism that may be involved is recombination, which enables the creation and spread of advantageous traits and that permits the removal of deleterious genes (Woroby \& Holmes 1999). Accumulated variation may be lost through natural selection or genetic drift. The passage of virus from one host to another is usually associated with extreme evolutionary bottlenecks, since in most cases only a few randomly selected infectious units are transferred. Genetic drift is therefore an important factor of viral evolution and the establishment of distribution patterns of virus isolates (Hungnes et al. 2000).

Based on knowledge from other viruses in the Orthomyxoviridae, the hemagglutinin (HA) gene is expected to show most sequence variation (Webster et al. 1992, Fitch et al. 1997, Lindstrom et al. 1999, Suarez et al. 1999, Hungnes et al. 2000). The HA gene has been identified and characterized by Krossøy et al. (2001b) and partly characterized by Rimstad et al. (2001) and Griffiths et al. (2001). The preliminary comparison of a few Norwegian isolates shows that the gene contains a highly polymorphic region (HPR) and Krossøy et al. (2001b) suggests that the HA gene may contain enough variation for a separation of ISAV iso- lates. This study presents sequence variation of the HA gene from 37 ISAV isolates. Sequences of this gene from Canadian, Scottish, and Norwegian isolates are presented and compared, and the evolutionary relationship between the isolates calculated.

\section{MATERIALS AND METHODS}

ISAV strains. The different ISAV strains were collected by the National Veterinary Institute (Oslo) and Department of Fisheries and Marine Biology, University of Bergen, from outbreaks of the disease in salmon farms along the Norwegian coast, during the period from 1987 to 2000 (Table 1). The Canadian strains were collected in 1998 from salmon farms in New Brunswick and were supplied by Steve Griffiths (Table 1). The Scottish isolate was collected in 1998 in Loch Nevis and sent to the National Veterinary Institute in Norway (Table 1). The different ISAV isolates were collected from the kidney of Atlantic salmon Salmo salar with clinical signs of ISA and cultured in salmon head kidney-1 (SHK-1) cells or Atlantic salmon kidney (ASK) cells (cf. Devold et al. 2000).

It is well known that ISA infected smolts have been transported between different regions along the Norwegian coast. Smolts from the first official Norwegian outbreak of the disease in 1984 were transported from Bremnes (Hordaland) and as far as Tjeldsundet (southern Troms). Neither of these 2 isolates are available but the isolate from 1987 (isolate 1/87), included in this study, can also be connected to the 1984 outbreak at Bremnes (Fig. 1). For some of the isolates a possible connection due to transportation of ISA-infected material can be documented; however, in most cases we have been forced to suggest connections based on similarities of the HA gene from the different isolates.

Reverse transcription polymerase chain reaction (RT-PCR). The different ISAV strains were isolated in SHK-1 cells or ASK cells and the RNA was extracted after 2 or 3 passages using Trizol reagent (Life Technologies) according to standard protocols (cf. Devold et al. 2000). Reverse transcription was performed using Maloney Murine Leukemic Virus Reverse Transcriptase (MMLV-RT) (Promega) with random hexamers as primers (Devold et al. 2000). The cDNA was made from 30 different ISAV isolates. Subsequently, the singlestranded cDNA served as template in PCR using Taq DNA polymerase according to recommended conditions (Pharmacia). The following primers were used upstream primer (5'-GCA AAG ATG GCA TGA TTC-3') and downstream primer $\left(5^{\prime}\right.$-GTT GTC TTT CTT TCA TAA TC-3'). The reaction cycle was 4 min incubation at $94^{\circ} \mathrm{C}$ and 35 cycles of $94^{\circ} \mathrm{C}$ for $30 \mathrm{~s}, 55^{\circ} \mathrm{C}$ for $45 \mathrm{~s}$ and $72^{\circ} \mathrm{C}$ for $1 \mathrm{~min}$, followed by extension at $72^{\circ} \mathrm{C}$ for $10 \mathrm{~min}$. 
Table 1. Overview of the infectious salmon anemia (ISA) virus isolates and hemagglutinin sequences. The names of the different localities and the county they are located in are given in the first column. The code includes the number given to the isolates and the year of collection

\begin{tabular}{|c|c|c|c|c|}
\hline Locality & Year & Code & Accession no. & Comments \\
\hline \multicolumn{5}{|l|}{ NORWAY } \\
\hline \multicolumn{5}{|l|}{ Hordaland } \\
\hline Eikelandsosen & 1987 & $1 / 87$ & AF364893 & \\
\hline Golten & 1989 & $2 / 89$ & AF220607 & \multirow[t]{2}{*}{ Rimstad et al. (2001b } \\
\hline Sotra & 1991 & $6 / 91$ & AF364894 & \\
\hline Sotra & 1992 & $7 / 92$ & AF364898 & \\
\hline Sotra & 1993 & $8 / 93$ & AF309075 & \multirow[t]{2}{*}{ Krossøy et al. (2001b) } \\
\hline Varaldsøy & 1996 & $17 / 96$ & AF364891 & \\
\hline Bømlo (Bremnes) & 1998 & $36 / 98$ & AF302799 & Krossøy et al. (2001b) \\
\hline Strandebarm & 1998 & $40 / 98$ & AF364877 & \\
\hline Mundheim & 1998 & $45 / 99$ & AF364870 & \\
\hline Øygarden & 2000 & $51 / 00$ & AF364882 & \\
\hline Sørnes & 2000 & $56 / 00$ & AF364880 & \\
\hline \multicolumn{5}{|l|}{ Sogn og Fjordane } \\
\hline Landøy & 1996 & $18 / 96$ & AF364869 & \\
\hline Gulen & 1998 & $41 / 98$ & AF364871 & \\
\hline Skatestraumen & 1999 & $48 / 99$ & AF364878 & \\
\hline Nordfjord & 1999 & 47/99 & AF364888 & \\
\hline Solund & 2000 & $54 / 00$ & AF364884 & \\
\hline Fjaler & 2000 & $57 / 00$ & AF364890 & \\
\hline \multicolumn{5}{|l|}{ Møre og Romsdal } \\
\hline Selje & 1995 & $14 / 95$ & AF364873 & \\
\hline Misund & 1999 & $46 / 99$ & AF364896 & \\
\hline Lepsøy & 2000 & $52 / 00$ & AF364892 & \\
\hline \multicolumn{5}{|l|}{ Sør Trønderlag } \\
\hline Hitra & 1996 & $21 / 96$ & AF364886 & \\
\hline Hitra & 1997 & $26 / 97$ & AF364879 & \\
\hline Frøya & 1997 & $25 / 97$ & AF364885 & \\
\hline Frøya & 1997 & $27 / 97$ & AF364897 & \\
\hline Åfjord & 1997 & $28 / 97$ & AF364875 & \\
\hline Hitra & 1999 & $44 / 99$ & AF302803 & Krossøy et al. (2001b) \\
\hline \multicolumn{5}{|l|}{ Nord Trønderlag } \\
\hline Nærøy & 1998 & $38 / 99$ & AF364874 & \\
\hline \multicolumn{5}{|l|}{ Nordland } \\
\hline Vestvågøy & 1993 & $9-93$ & AF364895 & \\
\hline Torgnes & 1997 & $29-97$ & AF364872 & \\
\hline Dønna & 1998 & $32-98$ & AF364883 & \\
\hline Henningsvær & 1999 & $49-99$ & AF364876 & \\
\hline \multicolumn{5}{|l|}{ Troms } \\
\hline Gullesfjord & 1993 & $10 / 93$ & AF302801 & Krossøy et al. (2001b) \\
\hline Senja & 1996 & $22 / 96$ & AF364889 & \\
\hline Senja & 1998 & $33 / 98$ & AF364887 & \\
\hline Blåmannsvik & 1998 & $37 / 98$ & AF364881 & \\
\hline \multicolumn{5}{|l|}{ CANADA } \\
\hline New Brunswick & 1998 & $31 / 98$ & AF302800 & Krossøy et al. (2001b) \\
\hline \multicolumn{5}{|l|}{ SCOTLAND } \\
\hline Loch Nevis & 1998 & $43 / 98$ & AF302802 & Krossøy et al. (2001b) \\
\hline
\end{tabular}

the following upstream (5'-GAT CAA CGG ATG CGG ATA TTT CA-3'), (5'AAT TGA TGC TGC TTC GTG TG-3') and downstream primers (5'-GTC AAA ATC TTT AAC CAT CTT AGG GCA-3'), (5'-TGA CAC GTA GAT TTG TCC TTG G-3'). The products were run in an ABI 377 DNA analyzer (PE Biosystems).

If hosts are infected with 2 or several different virus isolates, natural selection will usually act to benefit 1 isolate or a combination of gene segments from the isolates in a co-infection, which means that, in most cases, one should only isolate 1 virus strain after inoculation on cell culture. Still, the possibility can not be excluded that the samples taken from infected fish may harbor more than 1 isolate. To avoid this problem all sequencing was carried out on PCR products (cf. Smith et al. 1997, Hungnes et al. 2000), which means that presence of more than 1 isolate could be visualized in the chromatographs.

The isolate 36/98 was passed 10 times through cell cultures (ASK cells) and then sequenced to see if culturing of the virus affected the original sequence. No changes in the sequence were observed.

Sequence analysis. The sequence data were assembled with the help of Vector NTI software (InforMax, Inc.) and the GenBank searches were done with BLAST (2.0). The Vector NTI Suite software package (InforMax, Inc.) was used for the multiple alignments of partial nucleotide and protein sequences. To perform pairwise comparisons between the different sequences from the 37 ISA isolates, the multiple sequence alignment editor GeneDoc $^{1}$ was used. Sequences already available on the EMBL nucleotide database were also included in the comparisons (cf. Table 1).

In addition to software analysis of

Sequencing. The PCR products were purified on Qia-quick PCR Purification columns (Qiagen) and then sequenced using the BigDye Terminator Sequencing kit. The isolates were sequenced from base 12 after the start codon to the end of the open reading frame (ORF) for all isolates. The sequencing was done using the amplification primers described above in addition to the sequences (see below), the HPR of the HA gene (Krossøy et al. 2001b) was manually aligned and compared for all isolates. This comparison was carried out

\footnotetext{
${ }^{1}$ GeneDoc: A full featured multiple sequence alignment editor, analyser and shading utility for Windows. Available at: www.psc.edu/biomed/genedoc
} 


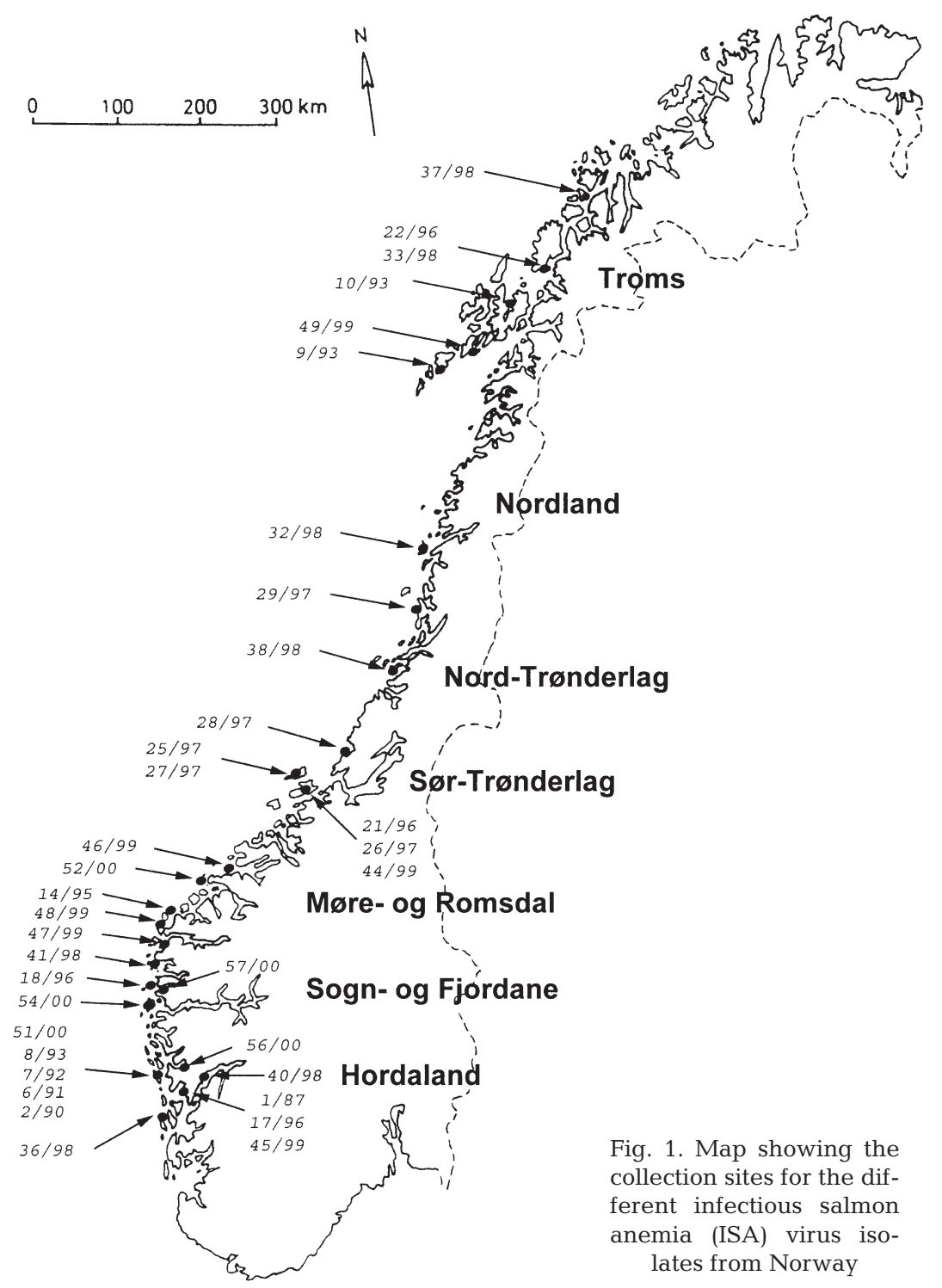

following analyses were done and compared: (1) quartet puzzling analyses using distance as optimal criterion $_{i}$ (2) distance method (general time reversal [GTR], with rates following a gamma distribution) with minimum evolution as search option; (3) maximum parsimony method with heuristic search; and (4) maximum likelihood method where a number of parameters were estimated from the dataset, and the model employed corresponds to a GTR model with rate heterogeneity $(G T R+G)$. Briefly, the base frequency was estimated from the dataset and kept constant during tree search, which was done through the heuristic search option. The first 3 methods used 10000 puzzling steps or bootstrap replicates. Phylogenetic trees were drawn using TreeView (Page 1996).

\section{RESULTS}

The ORF of the HA gene varies in length from 1188 base pairs (bp) (21/96) to 1152 bp (36/98) nucleotides, depending on the length of the HPR. The HPR spans from nucleotide 1012 to 1079 , with reference to the start of the ORF of isolate 21/96. Pairwise comparisons of the sequences from the 37 isolates show identities varying between 77 and $99 \%$ at the nucleotide level, with the Canadian isolate (31/98) being clearly sepa-

to see if any recombination events had occurred and to group the isolates based on this region only. Both regions flanking the HPR were compared separately since recombination in the HPR could give new isolates with flanking regions from 2 different isolates. This was done since conventional phylogenetic programs are constrained to produce simple branching trees and can lead to serious misinterpretation if sequence alignments are not carefully examined for evidence of recombination prior to tree reconstruction (cf. Worobey \& Holmes 1999). The phylogenetic analyses were carried out using natural groups with the same phylogenetic history, i.e. when possible recombination was detected, comparison of regions with presumed different phylogenetic histories was avoided.

Phylogenetic analyses of the data sets were performed using PAUP* 4.0 version (Swofford 1998). The rated from the European isolates. The identities between the European isolates range from 94 to $99 \%$, including the HPR. Most of the variation between the European isolates is due to differences in the HPR, while most of the variation between European and Canadian isolates is due to differences in the flanking regions. Comparison of the 5 '-end flanking region shows that the identities between the Canadian isolate and the Europeans isolates vary between 80 and $81 \%$, while the identities between the Europeans isolates at the 5 '-end flanking region range from 98 to $100 \%$.

The manual comparison of the HPR of the HA gene shows that before 1993 the HPR were represented by at least 2 distinct amino acid sequences: HPR1 (= PA TSVL SNI FIS) and HPR2 (= IRVDAI PPQL NQT). Comparison of later isolates gives clear indications of possible recombination involving these 2 HPR groups 
Table 2. Grouping of the ISA virus isolates based on the highly polymorphic region (HPR). Each column represents a combination of amino acids that seem to occur together. TDVK and MGVA represent the 4 first conservative amino acids sites on each side of the HPR. - - - followed/preceded by a letter represents substitutions and their position. Bold letters represent deviations from the most frequent patttern. Counties: $\mathrm{H}=$ Hordaland; $\mathrm{SF}=\mathrm{Sogn}$ og Fjordane; $\mathrm{T}=$ Troms; $\mathrm{N}=\mathrm{Nordland}$; NT $=\mathrm{Nord}$ Trønderlag; MR = Møre og Romsdal; ST = Sør Trønderlag

\begin{tabular}{|c|c|c|c|c|c|c|c|c|c|c|}
\hline & TDVK & $\longrightarrow$ & & $-\mathrm{H}$ & $\longrightarrow$ & - & - & MGVA & Year & Locality $^{\mathrm{a}}$ \\
\hline \multicolumn{11}{|l|}{ HPR1 } \\
\hline $1 / 87$ & & & & PA & TSVL & SNI & FIS & & 1987 & H-Eikelandsosen \\
\hline $7 / 92$ & & & & $\mathrm{PA}$ & TSVL & SNI & FIS & & 1992 & H-Sotra \\
\hline $8 / 93$ & & & & $\mathrm{PA}$ & TSVL & SNI & FIS & & 1993 & H-Sotra \\
\hline \multicolumn{11}{|l|}{ HPR2 } \\
\hline $2 / 89$ & & IRVDAI & & & PPQL & NQT & & & 1989 & H-Golten \\
\hline 6/91 & & IRVDAI & & & PPQL & NQT & & & 1991 & H-Sotra \\
\hline $18 / 96$ & & IRVDAI & & & PPQL & NQT & & L - - - & 1996 & SF-Landøy \\
\hline $22 / 96$ & & IRVDAI & & & PPQL & NQT & & & 1996 & T-Senja \\
\hline 33/98 & & IRVDAI & & & PPQL & NQT & & & 1998 & T-Senja \\
\hline $37 / 98$ & & IRVDAI & & & PPQL & NQT & & & 1998 & T-Blåmannsvik \\
\hline $38 / 98$ & & IRVDAI & & & PPQL & NQT & & & 1998 & NT-Nærøy \\
\hline \multicolumn{11}{|l|}{ HPR3 } \\
\hline 9/93 & & IRVDAI & & & PPQL & NQT & FIS & & 1993 & N-Vestvågøy \\
\hline \multicolumn{11}{|l|}{ HPR4 } \\
\hline $10 / 93$ & & IRVDAI & & & PPQL & SNI & FIS & & 1993 & T-Gullesfjord \\
\hline $31 / 98$ & $--\mathbf{N}$ & NRVDAI & & & PPQL & SNI & FIS & & 1998 & CANADA \\
\hline \multicolumn{11}{|l|}{ HPR5 } \\
\hline $14 / 95$ & & IRVDAI & & & PPQL & & -IS & & 1995 & MR-Selje \\
\hline \multicolumn{11}{|l|}{ HPR6 } \\
\hline $21 / 96$ & & IRVDAN & QVEQ & PA & TSVL & SNI & FIS & & 1996 & ST-Hitra \\
\hline $25 / 97$ & & IRVDAI & QVEQ & PA & TSVL & SNI & FIS & & 1997 & ST-Frøya \\
\hline $26 / 97$ & & IRVDAN & QVEQ & PA & TSVL & SNI & FIS & & 1997 & ST-Hitra \\
\hline $27 / 97$ & & IRVDAI & QVEQ & PA & TSVL & SNI & FIS & & 1997 & ST-Frøya \\
\hline $28 / 97$ & & IRVDAI & QVEQ & $\mathrm{PA}$ & TSVL & SNI & FIS & & 1997 & ST-Åfjord \\
\hline $44 / 99$ & & IRVDAN & QVEQ & PA & TSVL & SNI & FIS & & 1999 & ST-Hitra \\
\hline \multicolumn{11}{|l|}{ HPR7 } \\
\hline $17 / 96$ & & & & & TSVL & SNT & FIS & & 1996 & H-Varaldsøy \\
\hline $29 / 97$ & & & & & TSVL & SNI & FIS & & 1997 & N-Torgnes \\
\hline $32 / 98$ & & & & & TSVL & SNI & FIS & & 1998 & N-Dønna \\
\hline $36 / 98$ & $---\mathbf{E}$ & & & & TSVL & SNI & FIS & & 1998 & H-Bømlo (Bremnes) \\
\hline $40 / 98$ & & & & & TSVL & SNI & FIS & & 1998 & H-Strandebarm \\
\hline $41 / 98$ & $---\mathbf{E}$ & & & & TSVL & SNI & FIS & & 1998 & SF-Gulen \\
\hline $43 / 98$ & & & & & TSVL & SNI & FIS & & 1998 & SCOTLAND \\
\hline $45 / 99$ & $---\mathbf{E}$ & & & & TSVL & SNI & FIS & & 1999 & H-Mundheim \\
\hline $49 / 99$ & & & & & TSVL & SNI & FIS & & 1999 & N-Henningsvær \\
\hline $51 / 00$ & & & & & TSVL & SNI & FIS & & 2000 & H-Øygarden \\
\hline $56 / 00$ & & & & & TSVL & SNI & FIS & & 2000 & H-Sørnes \\
\hline \multicolumn{11}{|l|}{ HPR8 } \\
\hline $46 / 99$ & & IRVDAI & & & PPQL & & & L - - - & 1999 & MR-Misund \\
\hline $48 / 99$ & & IRVDAI & & & PPQL & & & L - - - & 1999 & SF-Skatestraumen \\
\hline \multicolumn{11}{|l|}{ HPR9 } \\
\hline $47 / 99$ & & IRVDAI & & & PPQL & NQT & FNT & & 1999 & SF-Nordfjord \\
\hline \multicolumn{11}{|l|}{ HPR10 } \\
\hline $52 / 00$ & & IK & $--\mathrm{Q}$ & PA & TSVL & SNI & FIS & & 2000 & MR-Lepsøy \\
\hline \multicolumn{11}{|l|}{ HPR11 } \\
\hline $54 / 00$ & & IRVDAI & & & PP - - & RNI & FIS & & 2000 & SF-Solund \\
\hline $57 / 00$ & & IRVDAI & & & PP - - & RNI & FIS & & 2000 & SF-Fjaler \\
\hline
\end{tabular}

(Table 2). In addition, there are deletions and insertions of amino acids in the HPR in the years after 1993. It is possible to assemble the screened isolates into 11 HPR groups based on this region (Table 2). These groups are to a certain degree geographically specific, but isolates with the same HPR can be found 


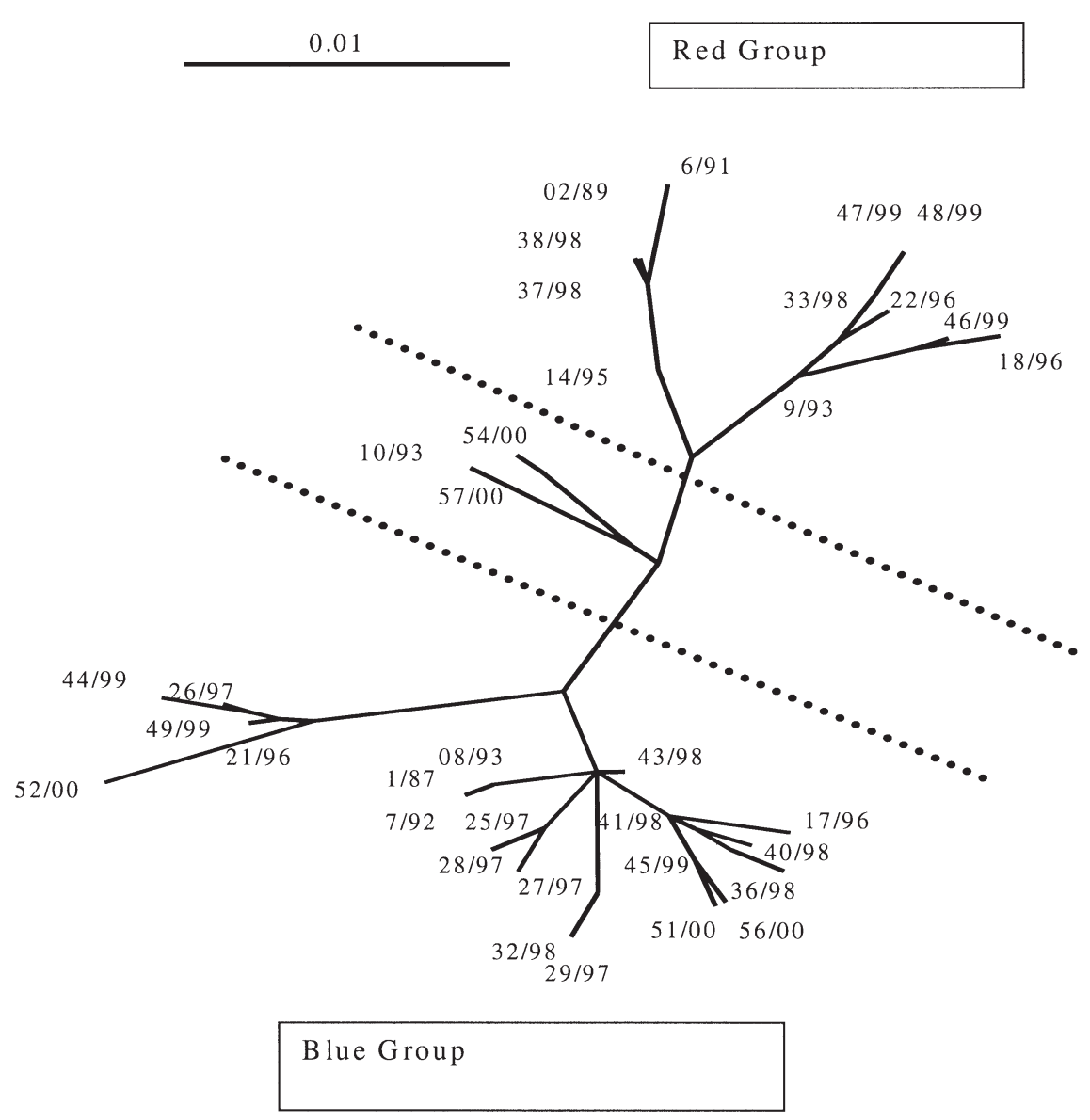

Fig. 2. Phylogeny resulting from full-length comparisons of hemagglutinin genes from the different ISA virus isolates given in Table 1 (the support values are low). They assemble into 2 major groups: the BLUE group, dominated by isolates with HPR1-related HPRs, and the RED group, consisting of isolates with HPR2-related HPRs. The phylogenetic analysis of the data sets was performed using PAUP* 4.0 (maximum likelihood method). Scale bar/branch length is proportional to the number of substitutions

as far apart as Troms and Hordaland (Table 2, Fig. 1). In certain areas there are also indications of changes in the HPR during the period of collection from 1987 to 2001. The most commonly observed changes are possible recombination and deletions of fixed segments of amino acids (Table 2), but neutral nucleotide substitutions (isolates 21/96, 26/97, 44/99, 49/00, and $56 / 00$ share the same neutral substitution in the third position of the $\mathrm{S}$ in the SNI segment) and a few single amino acid substitutions (isolates 21/96, 26/97, 17/96, 44/97, 47/99, 52/00, 54/00, and 57/00) are also observed (Table 2). When possible recombination has occurred within the HPR, the first part (5'-end) is always from the HPR2 group while the latter always comes from the HPR1 group of isolates (cf. Table 2). There is 1 group of isolates (HPR6 group) where an insertion (amino acid sequence $=$ QVEQ) seems to have occurred (Table 2).
The phylogeny resulting from full-length comparisons of HA from the different isolates showed 2 major groups (Fig. 2). One group (BLUE) was dominated by isolates with HPR1 or an HPR that could be derived from HPR1, and the other group (RED) consisted of isolates with HPR2 or an HPR derived from this group. The Canadian isolate and the Norwegian isolates 10/93, $54 / 00$ and 57/00 came out in a position between these 2 groups. These isolates had about $50 \%$ of the HPR from each of the isolates HPR1 and HPR2 (cf. Table 2). The Canadian isolate is not included in Fig. 2 due to low identity with the Europeans isolates.

The majority of isolates with similar HPR had very similar flanking regions when located in the same geographical area and not too distantly separated in time. The 5 '-end flanking region (about $950 \mathrm{bp}$ ) contained more variation than the 3 'end flanking region (about $85 \mathrm{bp}$ ) due to the large difference in size. Hence, differences and similarities in the $5^{\prime}$-end flanking region would best reflect possible recombination events within or close to the HPR. A possible recombination event was considered to have happened when isolates with similar HPR had distinctly different 5 '-end flanking regions or when new combinations of HPR1 and HPR2 occurred. One example is the isolates from Hitra/Frøya (HPR6) with similar HPR and closely related in time and space but separated by distinctly different $5^{\prime}$-end flanking regions (Fig. 3, Table 3). A possible recombination hot spot in the $5^{\prime}-$ end flanking region, an AU-rich sequence, was found between positions 901 and 912 with reference to the ORF.

Examples of possible recombination within the HPR region can be found in isolates belonging to HPR groups 3 to 6 and 9 to 11. The HPR groups 7 and 8 could be results of deletions, i.e. deletion of the amino acids PA from HPR1 gives the HPR7 group, and deletion of the amino acids NQT from the HPR2 gives the HPR8 group (Table 2). The HPR6 group seems to be a possible recombination between the HPR1 and HPR2, but it has, in addition, a new block of amino acids (QVEQ) inserted into the HPR (Table 2). The Canadian 


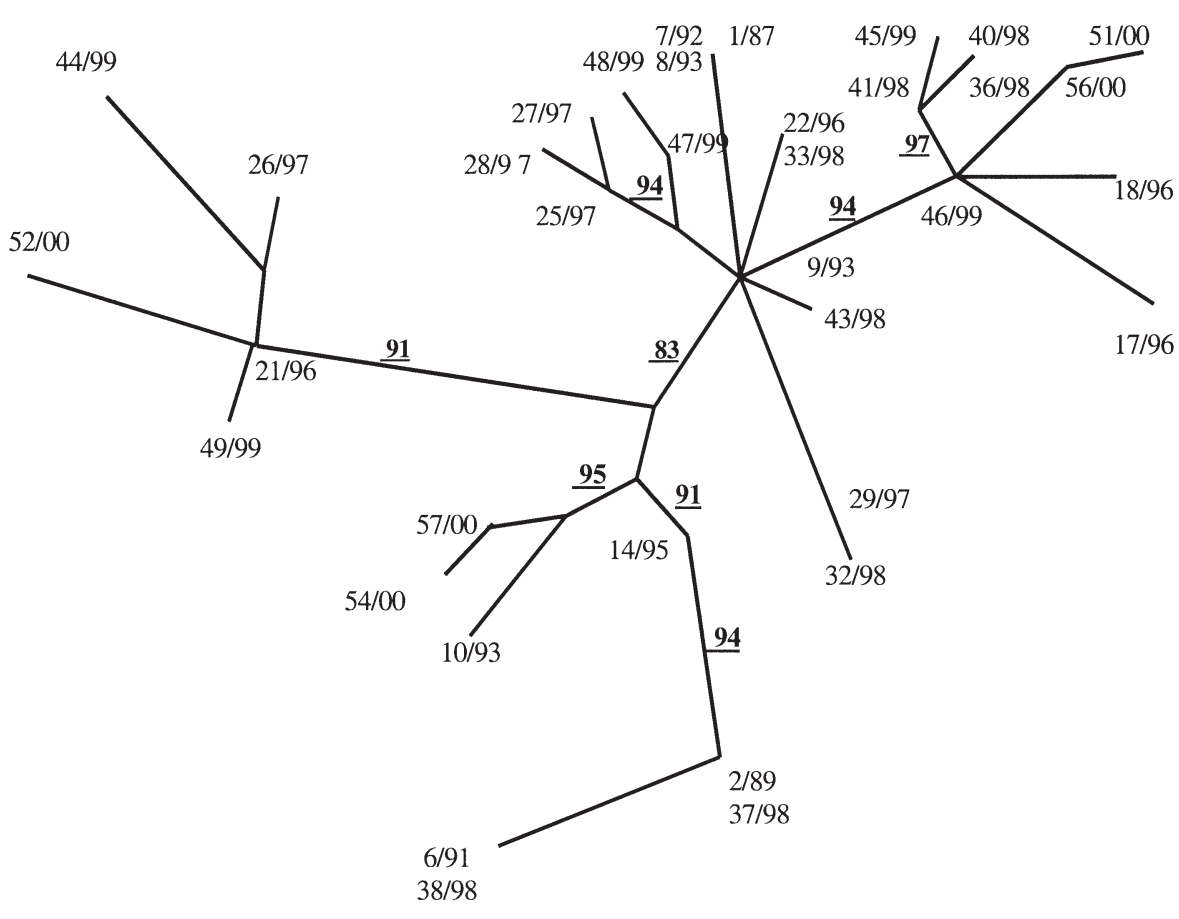

0.01

The phylogeny resulting from comparison of the 5'end flanking region of the HA gene from the different isolates is different from that of the full-length comparison (Figs 2 \& 3). The distinct separation of the isolates into a BLUE and RED group is lost. Some groups of isolates keep their close association with each other but change position in the phylogeny with respect to other groups. Two isolates, 18/96 and 46/99, changed position and lost their association with isolates within the RED group and became associated with isolates within the HPR7 (BLUE) group (support value $=94$ ) . Another group of isolates from within the RED group (9/93, 22/96, 33/98, 47/99, and 48/99) also moved to a closer association with isolates in the BLUE group (support value $=83$ ). Part of the BLUE group, consisting of isolates from Hitra $(21 / 96$, 26/97, and 44/99), 1 isolate from Nordland (49/99), and 1

Table 3. Support values for selected groups in the phylogeny based on the 5'-end flanking region to the HPR of the hemagglutinin gene (puzzle)

\begin{tabular}{|lcc|}
\hline Isolates & HPR group & Support \\
\hline 21/96, 26/97, 44/99, 49/99, 52/00 & $6,7,10$ & 91 \\
$10 / 93,54 / 00,57 / 00$ & 4,11 & 95 \\
$54 / 00,57 / 00$ & 11 & 79 \\
$2 / 89,6 / 91,14 / 95,37 / 98,38 / 98$ & 2,5 & 91 \\
$2 / 89,6 / 91,37 / 98,38 / 98$ & 2 & 94 \\
$25 / / 97,27 / 97,28 / 97$ & 6 & 94 \\
$27 / 97,28 / 97$ & 6 & 98 \\
$48 / 99,47 / 99$ & 8,9 & 89 \\
$22 / 96,33 / 98$ & 2 & 100 \\
$36 / 98,40 / 98,41 / 98,45 / 99$ & 7 & 97 \\
$36 / 98,40 / 98$ & 7 & 100 \\
$51 / 00,56 / 00$ & 7 & 68 \\
$1 / 87,7 / 92,8 / 93$ & 1 & 57 \\
$29 / 97,32 / 98$ & 7 & 66 \\
\hline
\end{tabular}

isolate has for the sake of convenience been assigned to HPR4 (a possible recombination between HPR1 and HPR2) but is in reality slightly different from the other isolate in this group (cf. Table 2). from Møre og Romsdal (52/00), moved from a position within the BLUE group and into a closer association with isolates within the RED group (Fig. 3). The other isolates (25/97, 27/97, and 28/97), with an HPR similar to that of the Hitra isolates (HPR6), kept their association with isolates in the BLUE group. The phylogeny based on the $5^{\prime}$-end flanking region gave groups that were more strongly supported than the phylogeny based on the whole HA segment (Fig. 3, Table 3).

\section{DISCUSSION}

The choice of ISAV isolates included in this study is strongly biased towards the last 7 yr (1994 to 2000). It has only been possible to obtain 6 isolates collected before 1994. The year 1994 was the all time low with respect to ISA in Norway; only 1 case was recorded officially (Håstein et al. 1999). Preceding this was a period (1989 to 1992) with a very high number of new cases of ISA. Nearly 100 new cases were registered each year in 1990 and 1991. This high number of new cases coincided with a period with few constraints on 
transportation of eggs and smolts along the Norwegian coast. In addition, there were no regulations on disinfection of waste-water and offal from fish slaughterhouses, or disinfection of intake of water to hatcheries (Håstein et al. 1999). These regulations were introduced in 1991 but probably did not become effective until a year later. Hence, most of the transportation of ISAV isolates along the Norwegian coast probably occurred before 1994 (cf. Håstein et al. 1999). However, smolts are still transported along the Norwegian coast and ISA-infected salmon are also transported from infected farms to different slaughterhouses. Choice of slaughterhouse seems to be determined by the price that the farmers can get for salmon from infected farms. Salmon from infected farms have been transported as far as from Troms to Sør-Trønderlag. Even if all precautions were taken, there is always a chance that this transportation may have transmitted different ISAV isolates between the regions included in this study. Hence, we may expect that an otherwise clear geographical and chronological pattern may be occluded. Risk factors involved in the spread of ISAV have been studied by Jarp \& Karlsen (1997).

The strength of the choice of isolates is also weakened by the fact that we lack ISAV isolates from the period before salmon farming started in Norway, and by the fact that there are strong indications that ISA occurred in Norwegian salmon farming as early as in the late 1970 s, i.e. many years before the first official outbreak in 1984. An additional weakness is that there are no isolates from wild fish included. Bearing these constraints in mind, the chosen isolates should give a fairly good picture of the spread and distribution of ISAV isolates during the last $7 \mathrm{yr}$ in Norway. The isolate 1/87 (Eikelandsosen) can be connected to the first official outbreak of ISA in Norway (in Bremnes in 1984) and represents the best possible starting point.

The HA gene, probably segment 6, of the ISAV genome has already been identified and characterized (Krossøy et al. 2001b, Rimstad et al. 2001). Among the influenza viruses the most polymorphic gene has been shown to be the HA gene (Webster et al. 1992), which makes this sequence a possible tool in the separation of closely related isolates. Earlier sequence comparisons of ISAV gene segments 2 and 8 have shown distinct differences between isolates from eastern North America and Europe (Blake et al. 1999, Cunningham \& Snow 2000, Krossøy et al. 2001a), but it has not been possible to obtain satisfactory resolution of the different European isolates. The variation in the HA gene of the European ISAV isolates is higher than that observed for segment 2 and 8 , and most of the variation is due to the HPR. There are 2 major HPR groups where one group is dominated by HPR1-related isolates (BLUE) and the other dominated by HPR2-related isolates (RED).
The phylogeny based on the nucleotide sequence of the HA gene reflects the influence of the HPR as a major site of variation (cf. Fig. 2). The phylogeny gives 2 major clusters, i.e. the BLUE and RED clusters, where the isolates in the BLUE cluster are dominated by HPR1-related isolates and the RED cluster by HPR2related isolates. However, this phylogeny is based on conventional phylogenetic programs without adjusting for possible recombination events. Comparisons of the 11 different HPR groups give indications of possible recombination events within this region, where the resulting HPR groups (HPR3, 4, 5, 6, 9, 10, and 11) always have an amino acid sequence from the HPR2 group at the amino end and an amino acid sequence from the HPR1 group at the carboxyl end. The isolates in the HPR6 group have an additional 4 amino acid sequence (QVEQ), the origin of which cannot be explained as recombination between HPR1- and HPR2-related isolates only. This additional amino acid sequence could be the result of an insertion or recombination with a not yet identified isolate. The largest part of the HPR6 is related to the HPR1 group (BLUE group). The HPR10 and HPR11 groups (isolates 52/00 and 54/00,57/00) are best understood as the result of deletion of some amino acids from isolates within the HPR6 group. In addition there is a substitution of 1 amino acid in the HPR of isolates 54/00 and 57/00 (SNI to RNI). Deletion of specific amino acid segments is also the most parsimonious explanation for the HPR7 and HPR8 groups where loss of 2 amino acids from HPR1 results in HPR7 and loss of 3 amino acids from HPR2 results in HPR8 (cf. Table 2).

Most of the possible recombination events observed in the last 2 yr (1999 and 2000) seem to have occurred in the Sogn- og Fjordane/Møre og Romsdal (SF/MR) area. The HPR groups (HPR9 to 11) from these area also show a tendency towards deletions and substitutions of amino acids, changing an otherwise fixed pattern of amino acids in the HPR. This geographic area is situated between 2 areas (Hordaland and Sør-Trønderlag) where isolates in groups HPR7 and HPR6, respectively, have dominated with little change during the period from 1995 to 2000. At present, no well-founded arguments can be given for what seems to be a high level of evolutionary activity in the SF/MR area as opposed to the stable situation in Hordaland and SørTrønderlag. One explanation could be that the former area represents a hybridization zone between the latter 2 areas. However, more isolates should be screened before such a conclusion is made.

In addition to possible recombination events within the HPR there are also indications of recombination in the 5 '-end flanking region close to the HPR (positions 901 to 912 ). The phylogeny based on the 5 '-end flanking region only shifts the position of some of the iso- 
lates (cf. Figs $2 \& 3$ ). The support values for the phylogeny based on the 5 '-end flanking region are much higher than those for the phylogeny based on the whole HA segment, which suggests that finding true relationships between the different isolates has to take into consideration possible recombination events.

Homologous recombination events require that at least 2 different isolates are present in the host at the same time infecting the same cell. Worobey \& Holmes (1999) reviewed the evolutionary aspects of recombination in RNA viruses, i.e. detection of recombination, and evolutionary advantages of, and constraints on, recombination. It is too early to have any firm opinion on the evolutionary advantages of recombination of the HA gene in the ISAV isolates, but when recombination seems to occur within the HPR, it always results in an HPR1-associated 3'-end and an HPR2-associated 5'-end (isolates in HPR groups 3, 4, 5, 6, 9, 10, and 11). In addition, it seems that new recombinations occur when ISA outbreaks cannot be connected to previous outbreaks, which suggests that new recombinations may occur in wild salmonids followed by a transfer to farmed Atlantic salmon. This is not unexpected, since previous studies of trout Salmo trutta have shown that infected trout may become life-time carriers of the ISAV (Nylund et al. 1995, Devold et al. 2000). Taking into consideration the long life-span of wild trout, their mobility (Berg \& Berg 1987), the high density of trout along the Norwegian coast, the presence of different ISAV isolates along most of the coast, and the possibility that trout may become life-time carriers, it is likely that the majority of homologous recombination events occur in this species in the wild. Homologous recombination of ISAV isolates in farmed Atlantic salmon may also occur, but the short life-span of the salmon and lack of farms with more than 1 isolate suggest that this may not be a frequent occurrence.

A phylogenetic analysis based on segment 2 from ISAV isolates from Norway, Scotland, and Canada has previously been published by Krossøy et al. (2001a). The present analysis based on HA is in conflict with this phylogeny. In the phylogeny based on the HA gene the isolates $2 / 90,10 / 93,17 / 96$, and 44/99 cluster in 4 different groups while in the phylogeny based on segment 2 (the putative RNA-dependent RNA polymerase) these isolates group together with high bootstrap support. There are several possible explanations for this discrepancy between the 2 phylogenies. The phylogeny based on segment 2 includes just a few isolates compared to the present study, which means that the resolution of the analysis will be different. It is also well documented that re-assortment may occur in viruses with segmented genomes (Fields et al. 1996), leading to different relationships depending on the segment used in the analysis. Hence, in future phylo- genetic analysis of ISAV isolates, several or all segments should be used to discern the true relationship between the different isolates.

A major problem for the management of infectious diseases is to keep track of the spread of the agents concerned. The sequence of the HA gene may not give a completely true phylogeny of the ISAV isolates, but it provides a powerful new tool for management and combatting the disease. It is now possible to follow the spread of isolates within and between different regions, providing valuable information about important factors involved in the spread of the virus. This tool may also be used in the future to solve conflicts about irresponsible work practices which may result in the spread of the disease. The present study provides good examples of the power of this tool. The outbreak of ISA in Frøya and Åfjord have been considered to be 2 separate events, even though the 2 sites have the same owner. However, the close similarity between the Frøya isolates (25/97 and 27/97) and the Affjord isolate (28/97) strengthens the assumption that this isolate may have been transmitted between these 2 regions. Another example is the accusation that there may have been ISAV transmission between $47 / 99$ and $54 / 00$ in 2000. This accusation can most likely be refuted due to large differences in the HA gene sequence, which suggests different origins of the 2 isolates. There are also examples of the possible spread of ISAV by well boats along the Norwegian coast. One example of this is the presence of the same isolate in a farm in Hordaland and in 2 farms as far away as Nordland, all visited by the same well boat within a short time period. However, it should be kept in mind that while this tool may offer strong evidence against direct transmission, molecular analysis can never prove direct transmission, but only state that the evidence is consistent with the claim.

Acknowledgements. Financial support for this work was provided by grant 128042/122 from the Norwegian Research Council. We are greatly indebted to Asgeir Østvik for historical information about possible connections between ISA outbreaks.

\section{LITERATURE CITED}

Berg OK, Berg M (1987) Migrations of trout, Salmo trutta L:, from the Vardnes River in northern Norway. J Fish Biol 31: $113-121$

Blake S, Bouchard D, Keleher W, Opitz M, Nicholson BL (1999) Genomic relationships of the North American isolate of infectious salmon anemia virus (ISAV) to the Norwegian strain of ISAV. Dis Aquat Org 35:139-144

Bouchard DA, Brockway K, Giray C, Keleher W, Merrill PL (2001) First report of infectious salmon anemia (ISA) in the United States. Bull Eur Assoc Fish Pathol 21:86-88 
Cunningham CO, Snow M. (2000) Genetic analysis of infectious salmon anaemia virus (ISAV) from Scotland. Dis Aquat Org 41:1-8

Devold M, Krossøy B, Aspehaug V, Nylund A (2000) Use of RT-PCR for diagnosis of infectious salmon anaemia virus (ISAV) in carrier sea trout Salmo trutta after experimental infection. Dis Aquat Org 40:9-18

Eliassen TM, Frøystad MK, Dannevig BH, Jankowska M, Brech A, Falk K, Romøren K, Gjøen T (2000) Initial events in infectious salmon anemia virus infection: evidence for the requirement of a low-pH step. J Virol 74:218-227

Falk K, Namork E, Rimstad E, Mjaaland S, Dannevig BH (1997) Characterisation of infectious salmon anemia virus, an Orthomyxo-like virus isolated from Atlantic salmon (Salmo salar L.). J Virol 71:9016-9023

Fields BN, Knipe DM, Howley PM (1996) Virology. Lippincott-Raven Publishers, Philadelphia

Fitch WM, Bush RM, Bender CA, Cox NJ (1997) Long term trends in the evolution of H(3) HA1 human influenza type A. Proc Natl Acad Sci USA 94:7712-7718

Griffiths S, Cook M, Mallory B, Ritchie R (2001) Characterisation of ISAV proteins from cell culture. Dis Aquat Org 45: $19-24$

Håstein T, Hill B, Winton JR (1999) Successful aquatic animal disease emergency programmes. Rev Sci Tech Off Int Epiz $18: 214-227$

Hungnes O, Jonassen TØ, Jonassen CM, Grinde B (2000) Molecular epidemiology of viral infections. How sequence information helps us understand the evolution and dissemination of viruses. Acta Pathol Microbiol Immunol Scand 108:81-97

Inglis JA, Bruce J, Cunningham CO (2000) Nucleotide sequence variation in isolates of infectious salmon anaemia virus (ISAV) from Atlantic salmon Salmo salar in Scotland and Norway. Dis Aquat Org 43:71-76

Jarp J, Karlsen E (1997) Infectious salmon anaemia (ISA) risk factors in sea-cultured Atlantic salmon Salmo salar. Dis Aquat Org 28:79-86

Jones SRM, MacKinnon AM (1999) Virulence and pathogenicity of infectious salmon anemia virus isolated from farmed salmon in Atlantic Canada. J Aquat Anim Health 11:400-405

Kibenge FSB, Garate ON, Johnson G, Arriagada R, Kibenge MJT, Wadowska D (2001) Isolation and identification of infectious salmon anaemia virus (ISAV) from Coho salmon in Chile. Dis Aquat Org 45:9-18

Koren CWR, Nylund A (1997) Morphology and morphogenesis of infectious salmon anaemia virus replicating in the endothelium of Atlantic salmon Salmo salar L. Dis Aquat Org 29:99-109

Krossøy B, Hordvik I, Nilsen F, Nylund A, Endresen C (1999) The putative polymerase sequence of infectious salmon anemia virus suggests a new genus within the Orthomyxoviridae. J Virol 73:2136-2142

Krossøy B, Nilsen F, Falk K, Endresen C, Nylund A (2001a) Phylogenetic analysis of infectious salmon anaemia virus isolates from Norway, Canada and Scotland. Dis Aquat Org 44:1-6

Krossøy B, Devold M, Sanders L, Knappskog PM and 6 others (2001b) Cloning and identification of the Infectious salmon anemia virus hemagglutinin. J Virol 82:1757-1765

Lindstrom SE, Hiromoto Y, Nishimura H, Saito T, Nerome R, Nerome K (1999) Comparative analysis of evolutionary mechanisms of the hemagglutinin and three internal protein genes of influenza B virus: multiple cocirculating lin- eages and frequent reassortment of the NP, M, and NS genes. J Virol 73:4413-4426

Lovely JE, Dannevig BH, Falk K, Hutchin L, MacKinnon AM, Melville KJ, Rimstad E, Griffiths SG (1999) First identification of infectious salmon anaemia virus in North America with haemorrhagic kidney syndrome. Dis Aquat Org 35: 145-148

Mjaaland S, Rimstad E, Falk K, Dannevig BH (1997) Genomic characterization of the virus causing infectious salmon anemia in Atlantic salmon (Salmo salar L.): an orthomyxolike virus in a teleost. J Virol 71:7681-7686

Mullins JE, Groman D, Wadowska D (1998) Infectious salmon anaemia in salt water Atlantic salmon (Salmo salar L.) in New Brunswick, Canada. Bull Eur Assoc Fish Pathol 18: $110-114$

Nylund A, Alexandersen S, Jakobsen P, Rolland JB (1995) Infectious salmon anaemia (ISA) in brown trout. J Aquat Anim Health 7:236-240

Nylund A, Kvenseth AM, Krossøy B, Hodneland K (1997) Rainbow trout (Oncorhynchus mykiss, Walbaum, 1792): a carrier of infectious salmon anaemia (ISAV). J Fish Dis 20: $275-279$

Page RDM (1996) TREEVIEW: an application to display phylogenetic trees on personal computers. Comp Appl Biosci 12:357-358

Rimstad E, Mjaaland S, Snow M, Mikalsen AB, Cunningham CO (2001) Characterization of infectious salmon anemia virus genomic segment that encodes the putative hemagglutinin. J Virol 75:5352-5356

Ritchie RJ, Cook M, Melville K, Simard N, Cusack R, Griffiths $S$ (2001) Identification of infectious salmon anaemia virus in Atlantic salmon from Nova Scotia (Canada): evidence for functional strain differences. Dis Aquat Org 44: $171-178$

Rodger HD, Turnbull T, Muir F, Millar S, Richards RH (1998) Infectious salmon anaemia (ISA) in the United Kingdom. Bull Eur Assoc Fish Pathol 18:115-116

Rowley HM, Campell SJ, Curran WL, Turnbull T, Bryson DG (1999) Isolation of infectious salmon anaemia virus (ISAV) from Scottish farmed Atlantic salmon, Salmo salar L. J Fish Dis 22:483-487

Sandvik T, Rimstad E, Mjaaland S (2000) The viral 3'- and 5'end structure and mRNA transcription of infectious salmon anaemia virus resemble those of influenza viruses. Arch Virol 145:1659-1669

Smith DB, McAllister J, Casino C, Simmonds P (1997) Virus 'quasispecies': making a mountain out of a molehill? J Gen Virol 78:1511-1519

Snow M, Raynard RS, Bruno DW (2001) Comparative susceptibility of Artic char (Salvelinus alpinus), rainbow trout (Oncorhynchus mykiss) and brown trout (Salmo trutta) to the Scottish isolate of infectious salmon anaemia virus. Aquaculture 196:47-54

Suarez DL, Garcia M, Latimer J, Senne D, Perdue M (1999) Phylogenetic analysis of $\mathrm{H} 7$ avian influenza viruses isolated from the live bird markets of the Northeast United States. J Virol 73:3567-3573

Swofford DL (1998) Phylogenetic analysis using parsimony and other methods, version 4.0. Sinauer Associates, Sunderland

Webster RG, Bean WJ, Gorman OT, Chambers TM, Kawaoka Y (1992) Evolution and ecology of influenza A viruses. Microbiol Rev 56:152-179

Worobey M, Holmes EC (1999) Evolutionary aspects of recombination in RNA viruses. J Gen Virol 80:2535-2543 